\title{
Exploratory Analysis of Influencing Variables on Deforestation in Ghana
}

\section{With Particular Interest in Energy Access}

\author{
IDCE 324 Intermediate Quantitative Methods Final Project \\ Clark University \\ Fall 2017 \\ By: Nara McCray
}

\begin{abstract}
The relationship between energy access and deforestation in Ghana is examined through this exploratory multivariate analysis. Variables of electrification rate, wood use as cooking fuel, built-up area, population density, cropland area, and education are used to understand the relative influence of energy access on deforestation. This research uses RStudio, GeoDa and SPSS software to perform statistical processes: enter and stepwise multivariate linear regression, cluster analysis, and Bivariate Local Indicators of Spatial Association (BiLISA). The methods conducted at the sub-national scale improve upon on recent research that found wood use as cooking fuel to be a significant driver of deforestation that is being minimized by increasing access to electricity. This research conversely reveals that energy access is in fact influencing an increase in deforestation in Ghana.
\end{abstract}




\section{Introduction}

Deforestation of commonly attributed to urban expansion, population growth and economic growth associated with development. Recent research has provided evidence of a previously neglected correlation between deforestation and energy access in rural areas (Tanner, 2017). Through multivariate regression of 158 nations this study found that rural electrification causes decreases in deforestation rates. This is due to the subsistence lifestyle of rural communities. The most basic and dependable source of fuel for cooking in rural areas of developing countries is wood. When this biofuel is consumed at rates that surpass the regeneration period for forests, deforestation occurs. Providing alternative cooking fuels such as electricity can potentially reduce deforestation pressures while additionally providing other economic and wellbeing related benefits.

The reality is that there are over 1.1 billion people living today without access to electricity. As access to electricity increases rural areas may be weaned off of biofuel but this access to a new energy source may also increase production leading to an increase in deforestation rates. The relationship between the two is suggested to be a negative one based off of the Tanner research; as electrification increases, deforestation decreases. But, this can vary by location and other variables.

This research improves upon the Tanner research by conducting the multivariate analysis at a sub-national level with similar variables. The country chosen for this research is Ghana because of it's rapid increase in energy access over the past decade. The unit of analysis is district. Deforestation is the independent variable; it is expected to be influenced to some degree by the independent variables in this analysis. This paper will highlight the relationship between energy access and deforestation. Energy access is a measure gauged though household survey on household connectivity to electricity. Wood use as cooking fuel is another independent variable used to understand the use of wood as a fuel to proxy how sever deforestation pressures are. Population density is an independent variable used to account for demand on natural resources and to quantity the urban/rural variances. Built-up area is an indicator of economic success and development as well as natural resource demand. Crop land 
is an independent variable used to account for the rural/urban split and land pressure to convert forest to agriculture. Education is the final independent variable and it is used to account for privilege/socioeconomic status and awareness of environmental reproductions of using wood as cooking fuel. This variable specifically gauges the education rates of female survey respondents. Female respondents who are able to receive any form of education are likely to have more freedom and spend less time doing housework like collecting fire wood.

This scenario will be tested and demystified using statistical techniques of multivariate linear regression and cluster analysis. The multivariate analysis will reveal to what extent the different independent variables are influencing deforestation in Ghana. The cluster analysis will reveal the natural grouping trends of Ghana using the variables as district characteristics. This component of the analysis is predicted to reveal a breakdown between urban and rural districts. Urban areas with high population density are estimated to experience high energy access and high deforestation rates due to higher economic development while rural areas will be the opposite.

\section{Research Questions:}

What is the relationship between energy access and deforestation in Ghana?

Do changes in fuelwood demand affect deforestation in Ghana?

\section{Data}

\begin{tabular}{|c|c|c|c|c|}
\hline Variable & Type & Relevance & Categories & Source \\
\hline Deforestation & Dependent & $\begin{array}{l}\text { proportion of district land surface } \\
\text { that experienced forest loss } \\
\text { since } 2001 \text { to } 2016\end{array}$ & $\begin{array}{l}\text { 1- Loss } \\
0-\text { No Loss }\end{array}$ & $\begin{array}{l}\text { Hansen Forest Loss } \\
\text { Raster Data: 2009-2014 } \\
\text { https://explorer.earthengin } \\
\text { e.google.com/\#detail/UM } \\
\text { D\%2Fhansen\%2Fglobal } f \\
\text { orest change 2015 v1 } 3 \\
\end{array}$ \\
\hline $\begin{array}{l}\text { Energy } \\
\text { Access } \\
\text { Rates }\end{array}$ & Independent & $\begin{array}{l}\text { Rates of access to energy by } \\
\text { district in the year } 2014 \text {. } \\
\text { Approximation from household } \\
\text { survey. }\end{array}$ & $\begin{array}{l}\text { 1- Dwelling has electricity } \\
0 \text { - Dwelling does not have } \\
\text { electricity }\end{array}$ & $\begin{array}{l}\text { IPUMS DHS 2014: } \\
\text { https://www.idhsdata.org/i } \\
\underline{\text { dhs/ }}\end{array}$ \\
\hline $\begin{array}{l}\text { Wood-Based } \\
\text { Cooking Fuel } \\
\text { Use }\end{array}$ & Independent & $\begin{array}{l}\text { Measure of availability of } \\
\text { alternative fuels, wood is a } \\
\text { simple and basic source. High } \\
\text { use of wood as cooking fuel } \\
\text { indicates lack of alternatives and } \\
\text { reliance on forest for } \\
\text { subsistence and is indicative of } \\
\text { deforestation pressures. }\end{array}$ & $\begin{array}{l}\text { 100- Electricity } \\
\text { 200- Petroleum-based } \\
\text { 210- Gasoline } \\
\text { 220- - LPG, natural gas } \\
\text { 221- LPG (liquefied petroleum gas) } \\
\text { 222- Natural gas } \\
\text { 230- Bottled gas (butane or propane) } \\
\text { 240- Kerosene } \\
\text { 300- Biogas } \\
\text { 400- Coal-based } \\
\text { 410- Coal, lignite } \\
\text { 411- Coal, coke, lignite } \\
\text { 500- Wood- or grass-based }\end{array}$ & $\begin{array}{l}\text { IPUMS DHS 2014: } \\
\text { https://www.idhsdata.org/i } \\
\underline{\underline{\mathrm{dhs} /}}\end{array}$ \\
\hline
\end{tabular}




\begin{tabular}{|c|c|c|c|c|}
\hline & & & $\begin{array}{l}\text { 510- Wood } \\
\text { 520- Charcoal } \\
\text { 530- Firewood, straw } \\
\text { 540- Straw, shrub, grass } \\
\text { 600- Dung-based } \\
\text { 611- Animal dung } \\
\text { 612- Cow dung cakes } \\
\text { 613- Dung cakes } \\
\text { 700- Agricultural crop-based } \\
\text { 710- Crop residues } \\
\text { 720- Maize or other crop waste } \\
\text { 800- Other } \\
\text { 801- Jelly } \\
\text { 802- Solar } \\
\text { 995- No food cooked in house } \\
\text { 996- Non-resident } \\
\text { 998 -Missing } \\
\text { Transform to: } \\
\text { 1-Wood based } \\
\text { 0-Other }\end{array}$ & \\
\hline $\begin{array}{l}\text { Population } \\
\text { Density }\end{array}$ & Independent & $\begin{array}{l}\text { Measure of natural resource } \\
\text { demand and resulting human } \\
\text { influence on natural } \\
\text { environment. }\end{array}$ & \# of ppl per sq. km & $\begin{array}{l}\text { DHSstatcompiler 2015- } \\
\text { derived from WorldPop } \\
\text { http://www.worldpop.org.u } \\
\underline{\mathrm{k} /}\end{array}$ \\
\hline $\begin{array}{l}\% \\
\text { Agricultural } \\
\text { land }\end{array}$ & Independent & $\begin{array}{l}\text { Pressure to covert forests to } \\
\text { agricultural lands }\end{array}$ & 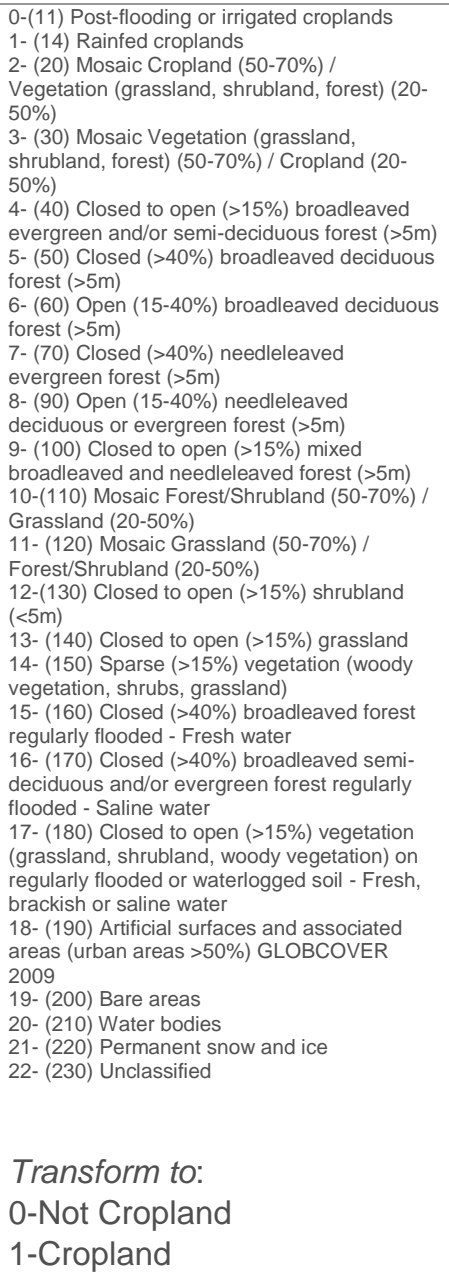 & $\begin{array}{l}\text { ESA GlobCover Map } \\
2009 \\
\text { https://explorer.earthengin } \\
\text { e.google.com/detail//SA } \\
\text { \%2FGLOBCOVER L4 2 } \\
00901200912 \text { V2 3 }\end{array}$ \\
\hline Education & Independent & $\begin{array}{l}\text { Proxy for } \\
\text { privilege/socioeconomic status } \\
\text { and understanding of } \\
\text { repercussions of deforestation }\end{array}$ & $\begin{array}{l}\text { 0- No education } \\
\text { 1- Primary } \\
\text { 2- Secondary } \\
\text { 3- Higher }\end{array}$ & $\begin{array}{l}\text { IPUMS DHS 2014: } \\
\text { https://www.idhsdata.org/i } \\
\underline{\underline{\text { dhs/ }}}\end{array}$ \\
\hline
\end{tabular}




\begin{tabular}{|c|c|c|c|c|}
\hline & & & $\begin{array}{l}\text { Transform to: } \\
\text { 0-No Education } \\
\text { 1-Some Education }\end{array}$ & \\
\hline Built-up land & Independent & $\begin{array}{l}\text { Indicator of wealth and } \\
\text { urbanization, economic } \\
\text { buoyancy and human influence } \\
\text { on environment. }\end{array}$ & $\begin{array}{l}0 \text { - Extreme Rural } \\
1 \text {-Extreme Urban }\end{array}$ & $\begin{array}{l}\text { DHSstatcompiler 2014- } \\
\text { derived from European } \\
\text { Commission Data } \\
\text { http:///data.jrc.ecc.europa.e } \\
\text { u/dataset/icc-ahsl- } \\
\text { ghs built Idsmt globe r2 } \\
015 \mathrm{~b}\end{array}$ \\
\hline
\end{tabular}

The unit of analysis for this study is Ghanaian districts of which there are 139 (HDX 2005). Deforestation is the dependent variable hypothesized to be influenced by the following independent variables: population, wood use a cooking fuel, energy access, education, built-up area and cropland. The deforestation data is derived from the popular Hansen forest loss dataset produced by Dr. Hansen of the University of Maryland (NASA/USGS 2015). This data exists in the form of a raster image which was clipped to the study area of Ghana and downloaded through Google Earth Engine. The data was then imported into RStudio, a R computer programming language software. Here, the number of pixels representing forest loss were summed by district and added as attributes to a districts shapefile. The percentage of agricultural land per district was calculated from a raster image which was also downloaded from Google Earth Engine and similarly processed (ESA 2009).

Three variables used for this study were obtained through the Demographic and Health Survey, which is an extensive global household survey. The most recent DHS survey conducted in Ghana was from 2014 which was administered to women. Variables sourced from this survey were education, energy access and wood use as cooking fuel. IPUMS is a database maintained by the University of Minnesota which compiles global census and survey conveniently aggregated across space and time (DHS 2017). This data unfortunately was not accompanied by spatial data, but cluster coordinates were available through the DHS StatCompiler website for the survey year of interest (DHS 2016). This spatial coordinate data was accompanied with variables for population density and built-up land for each cluster area, which are additional independent variables in this multivariate analysis. The data sourced from IPUMS and DHSstatcompiler were averaged by survey cluster number then further aggregated to district 
level. This results in categorical Boolean survey response values being transformed into the percentage values by district which is the unit of analysis.

\begin{tabular}{|l|r|r|r|r|r|r|}
\hline & \multicolumn{7}{|c|}{} \\
& \multicolumn{7}{c|}{ Descriptive Statistics } \\
& $N$ & Minimum & Maximum & \multicolumn{1}{c|}{ Mean } & Std. Deviation & Variance \\
\hline COOKFUEL14 & 139 & 10 & 52 & 30.93 & 9.176 & 84.198 \\
\hline ELECTRCHH14 & 139 & 24 & 96 & 70.75 & 16.174 & 261.610 \\
\hline EDUCLVL14 & 139 & 37 & 94 & 77.39 & 14.916 & 222.5010 \\
\hline Pop15 & 139 & 307.008 & 11795.339 & 1723.70187 & 1591.952380 & 2534312.379 \\
\hline Built14 & 139 & .0172 & .9347 & .234477 & .1647139 & .027 \\
\hline deforestALL & 139 & .000 & 23.077 & 5.24835 & 5.148052 & 26.5012 \\
\hline crop09 & 139 & .000 & 100.000 & 53.94574 & 34.258046 & 1173.614 \\
\hline Valid N (listwise) & 139 & & & & & \\
\hline & & & & & &
\end{tabular}

Table 2: Enter Regression Descriptive Statistics

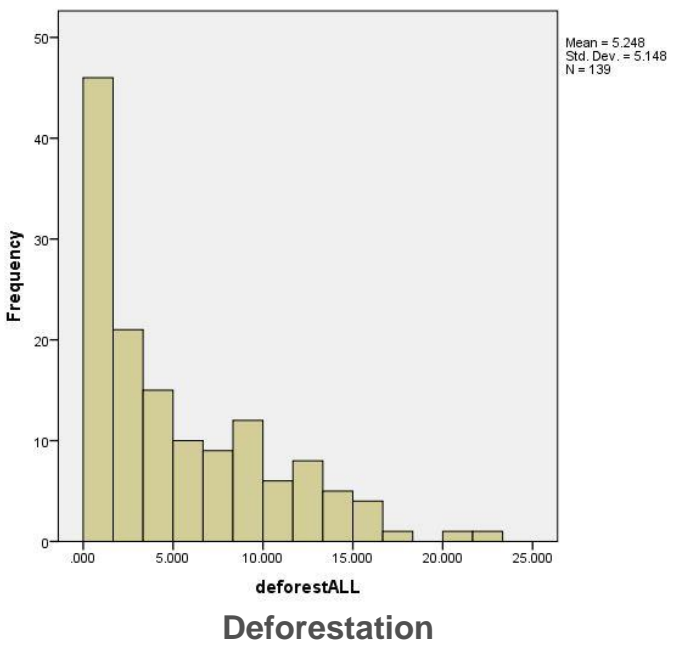

Chart 1: Deforestation Histogram
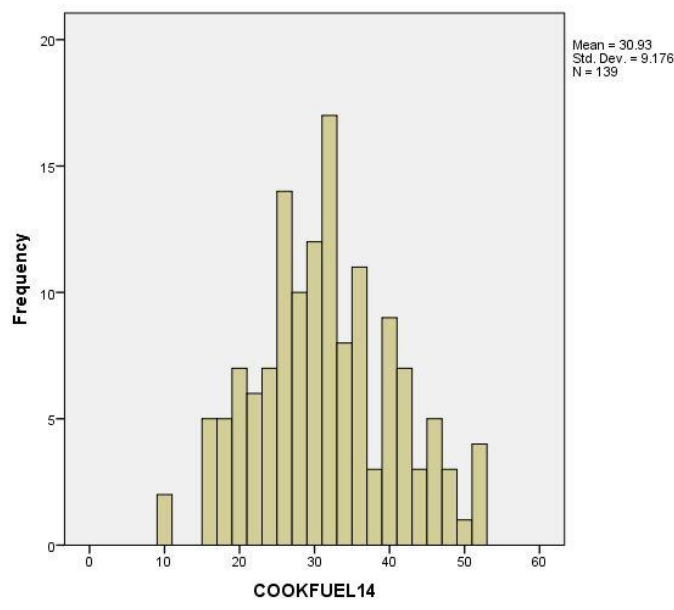

Wood Use as Cooking Fuel Chart 2: Wood Use Histogram

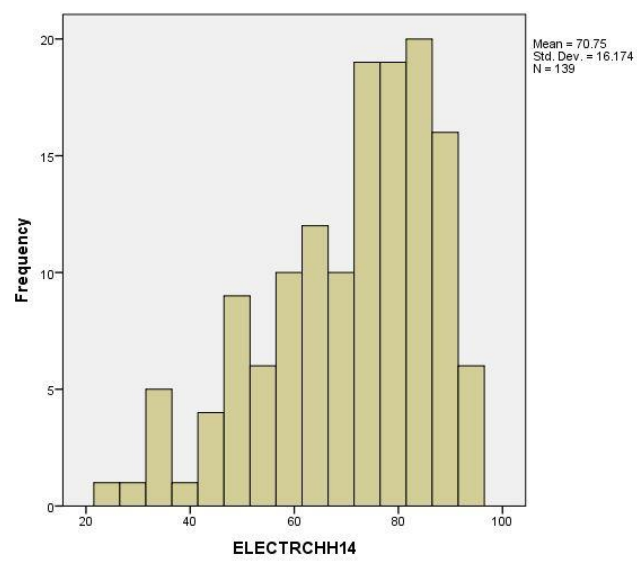

Electricity Access Chart 3: Electricity Histogram
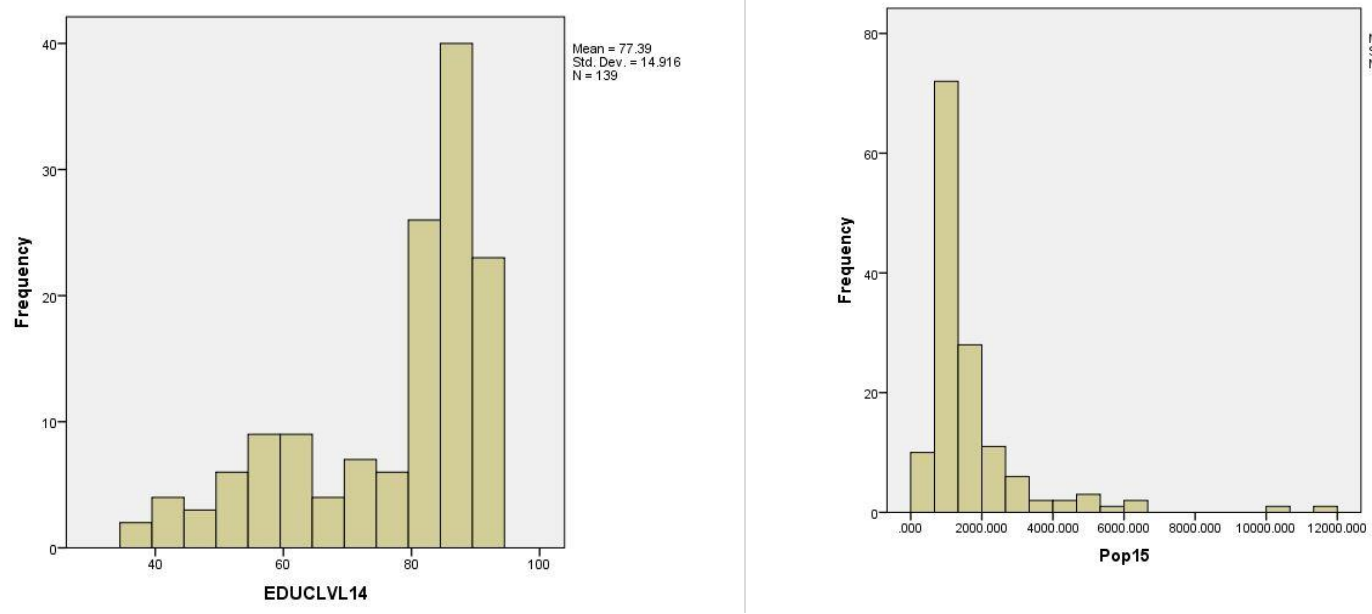

Mean $=1723.702$
Sad Dove.
$N=1591.952$ 


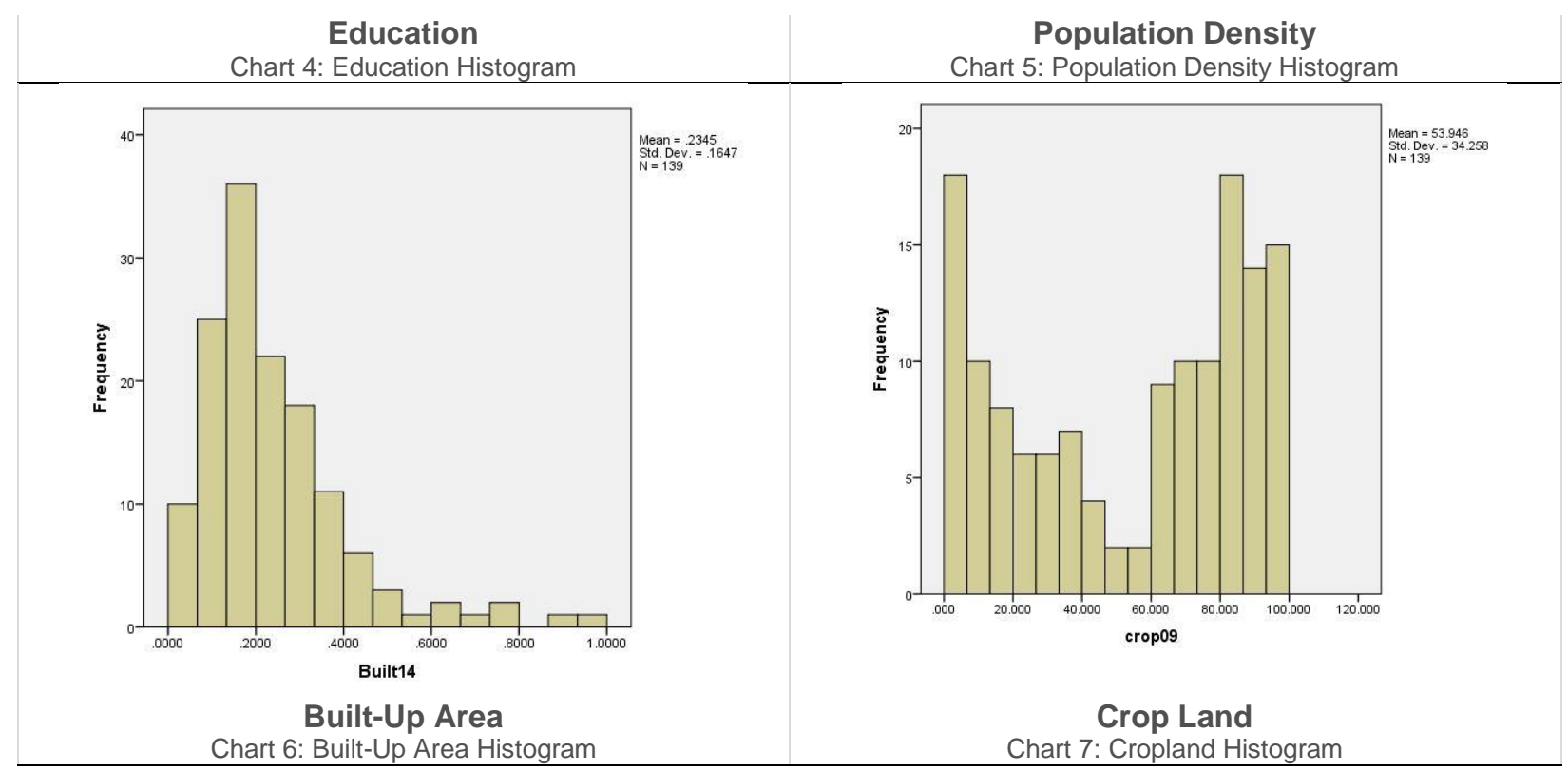

\section{Methodology}

\section{Multivariate Regression}

Enter Method: can be used to assess the extent to which several variables influence a dependent variable. This method is preferred for this research because although energy access rates may not influence deforestation as significantly as some of the other variables, we still want to see the relationship therefore we want to retain all independent variables. The prediction is that energy access will have a negative correlation with deforestation; high rates of energy access will be associated with low rates of deforestation. Also expected is that population density and built up area will have positive correlation with deforestation. The expected relationship between deforestation and wood use as cooking fuel is a positive one as will be percentage cropland. Education will be an interesting result because low education rates can be associated with high deforestation because low education is associated with severely rural areas that may rely most on trees for cooking fuel. High education rates may also be associated with high deforestation because of the association between high education and productive economies, which are associated with productivity and deforestation issues. 
Stepwise Method: can be used to assess the extent to which the most influential variables influence dependent variables. This method is relevant to this study so that we can examine which variables are most influencing deforestation rates in Ghana. The expectation is that built-up area and population will be the most influential to deforestation as deforestation is often associated with production and production is high in urban, built-up areas with high population density.

Cluster Analysis: this method reveals natural clustering in the unit of analysis based on the input variables. This is relevant to this study in order to understand how urban and rural areas differ in their deforestation and energy access characteristics and to examine if there are additional clusters aside from just urban and rural.

Local Moran's I: to detect the presence of clusters, local indicators of spatial association (LISA) were produced for deforestation and all independent variables. The Bivariate LISA analysis evaluates spatial autocorrelation between deforestation and the independent variables to reveal regional differences in relationships between the variable pairs. This is expected to reveal a split between urban and rural districts.

\section{Results}

\begin{tabular}{|c|c|c|c|c|c|c|c|c|}
\hline \multicolumn{9}{|c|}{ Correlations } \\
\hline & & deforestALL & $\begin{array}{c}\text { COOKFUEL1 } \\
4\end{array}$ & $\begin{array}{c}\text { ELECTRCHH } \\
14\end{array}$ & EDUCLVL14 & Pop15 & Built14 & crop09 \\
\hline \multirow[t]{7}{*}{ Pearson Correlation } & deforestALL & 1.000 & .382 & .550 & .528 & .186 & .387 & .649 \\
\hline & COOKFUEL14 & .382 & 1.000 & .759 & .621 & .492 & .663 & .287 \\
\hline & ELECTRCHH14 & .550 & .759 & 1.000 & .720 & .467 & .695 & .421 \\
\hline & EDUCLVL14 & .528 & .621 & .720 & 1.000 & .409 & .601 & .584 \\
\hline & Pop15 & .186 & .492 & .467 & .409 & 1.000 & .870 & .123 \\
\hline & Built14 & .387 & .663 & .695 & .601 & .870 & 1.000 & .300 \\
\hline & crop09 & .649 & .287 & .421 & .584 & .123 & .300 & 1.000 \\
\hline \multirow[t]{7}{*}{ Sig. (1-tailed) } & deforestALL & . & .000 & .000 & .000 & .014 & .000 & .000 \\
\hline & COOKFUEL14 & .000 & . & .000 & .000 & .000 & .000 & .000 \\
\hline & ELECTRCHH14 & .000 & .000 & . & .000 & .000 & .000 & .000 \\
\hline & EDUCLVL14 & .000 & .000 & .000 & . & .000 & .000 & .000 \\
\hline & Pop15 & .014 & .000 & .000 & .000 & . & .000 & .074 \\
\hline & Built1 4 & .000 & .000 & .000 & .000 & .000 & . & .000 \\
\hline & crop09 & .000 & .000 & .000 & .000 & .074 & .000 & \\
\hline
\end{tabular}

Table 3: Correlation Descriptive Statistics 
The summary statistics reveal that some for the variables are not normally distributed. All variables except for Wood Use as Cooking Fuel are either skewed or bimodal (CHART 2). This is not ideal for conducting a multivariate regression, but more important than normal data distribution of the variables is the distribution of the residuals. According to the partial residual plots, the relationships between deforestation and the independent variables are linear (PLOT 17). This is a sign that the resulting multivariate regression model is not under-estimating the true relationship. The results of the partial residual plots also indicating random scattering around 0 which indicates homoscedasticity. This is a good sign and assures that the variance of errors does not differ between independent variables.

\section{Multivariate Regression}

Enter Method- can be used to assess the extent to which various variables influence a dependent variable

Regression Equation: $Y p=-5.335-0.028$ COOKFUEL +0.107 ELECT -0.008 EDU $-0.001 P O P+6.515$ BUILT +0.074 CROP

The ANOVA chart shows how much variance is explained by the model, this is $\mathrm{F}=23$ for the enter method but higher for the Step method, F=99 (TABLE 5 and TABLE 9). This is because the two variables used in the Step method are the most robust in explaining the variance in deforestation and are therefore the best predictors to use in the model which produces a better result with an improved probability. The model summary produces the R squared which is similar for all models produces with both the Enter and Step methods of multivariate regression (TABLE 4).

The enter method produced a model where built-up area was the biggest influence on deforestation. With an increase of $1 \%$ built-up area, the predicted deforestation percent would increase by 6.515 (TABLE 6). Although this was the most powerful influencing factor because it has the biggest $B$ coefficient, the predictor with the most significance was cropland. The Coefficients Table (TABLE 6) also indicates that there might be some multicollinearity between population and built-up area because of the relatively high VIF values and relatively low tolerance values. This was a concern when selecting these as indicators because of the association between high population density and built-up areas. To verify the extent of this 
collinearity, the correlation table is referenced and it is clear that there is a high correlation of 0.87 between built-up area and population density (TABLE 3). There also appears to be a high correlation between wood use as cooking fuel and energy access.

The resulting regression equation is surprising. For every additional percent of wood use as cooking fuel, deforestation actually decreases by $0.028 \%$. For every additional percent of dwellings who receive access to electricity, deforestation increases by $0.107 \%$. This is counter to the initial hypothesis which is that using wood as cooking fuel is contributing to deforestation, while this regression model indicates that wood use as cooking fuel actually decreases deforestation. The relationship with energy access is therefore logical based on the COOKFUEL coefficient, and logical when considering that high rates of energy access are associated with urban areas which expand and likely influence deforestation.

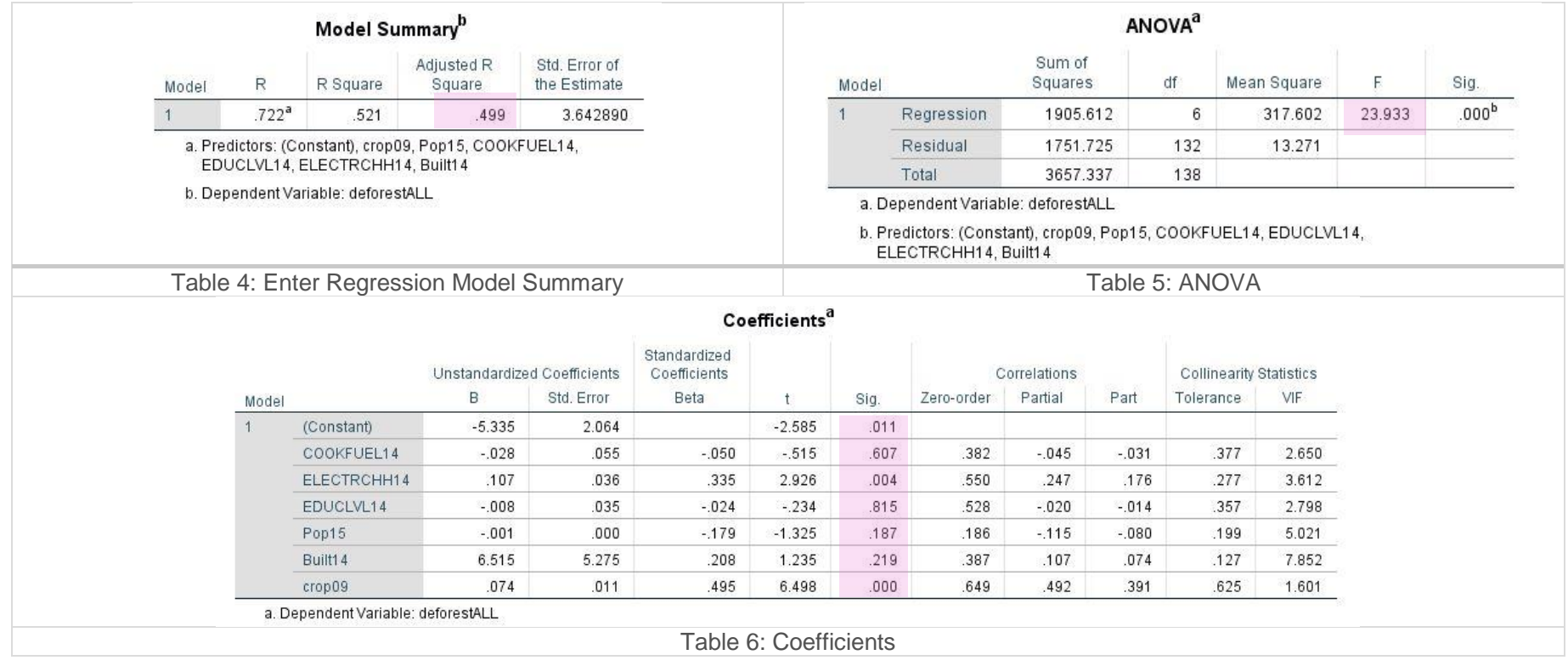



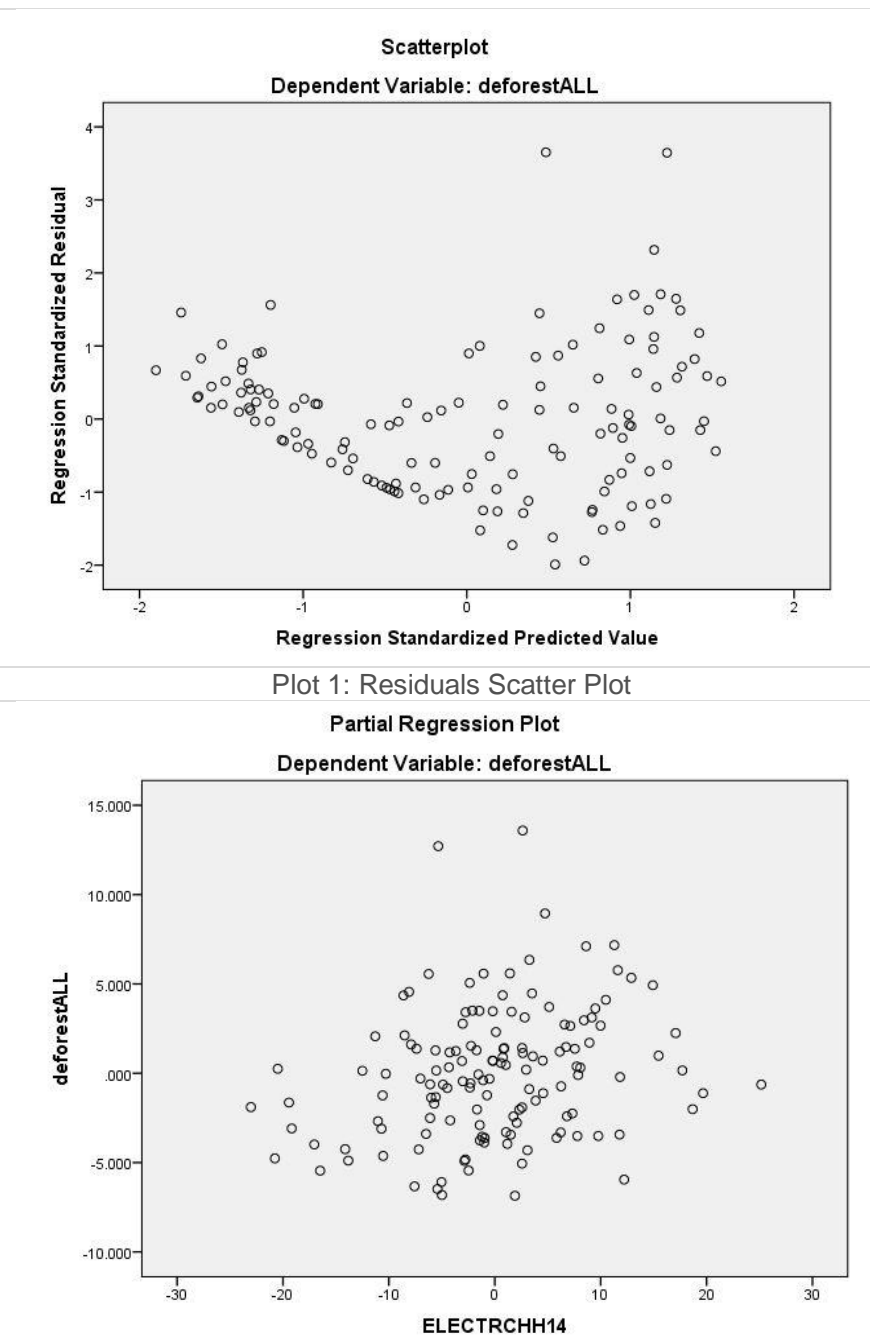

Plot 3: Electricity Access Residuals

Partial Regression Plot

Dependent Variable: deforestALL

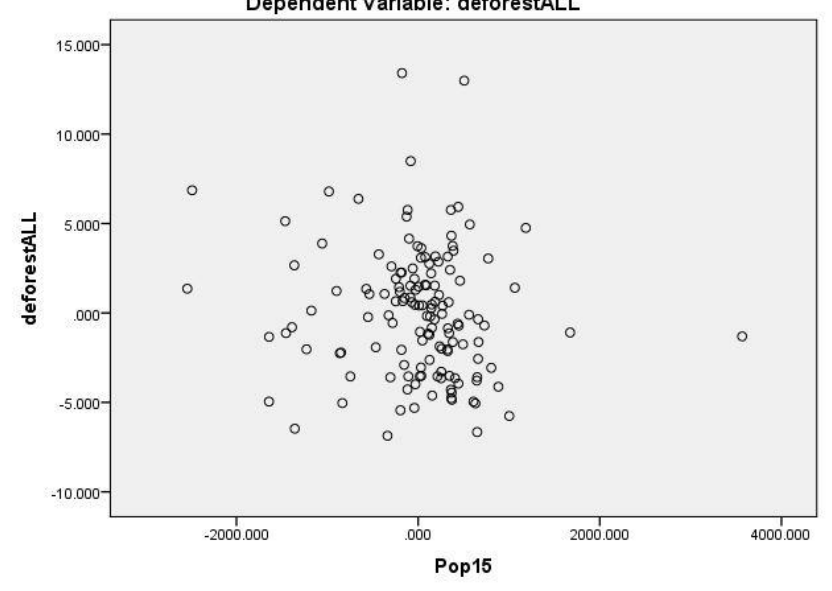

Plot 5: Population Density Residuals

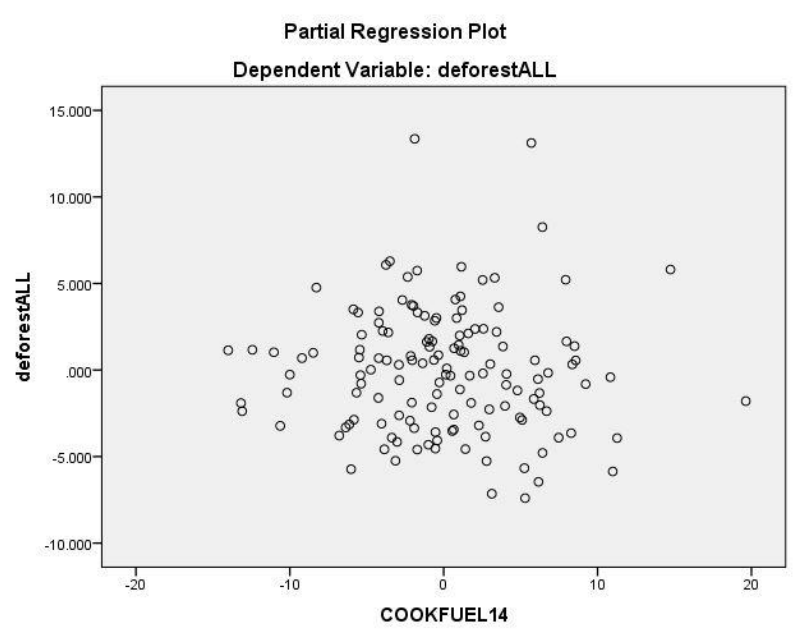

Plot 2: Wood Use Residuals

Partial Regression Plot

Dependent Variable: deforestALL

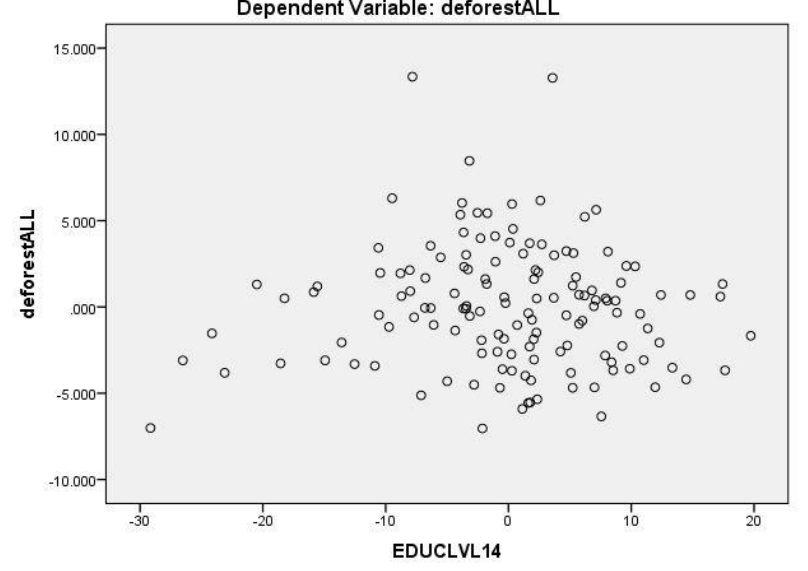

Plot 4: Education Residuals

Partial Regression Plot

Dependent Variable: deforestALL

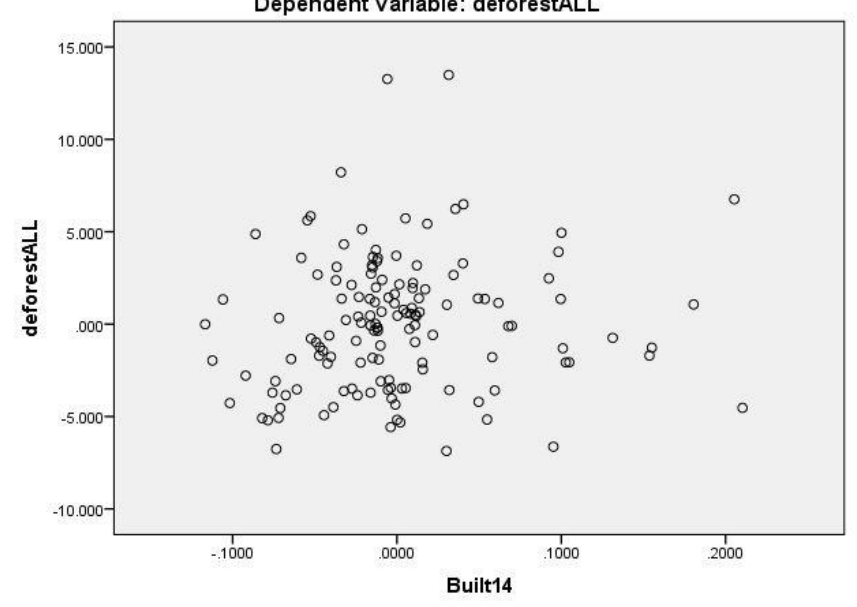

Plot 6: Built-up Residuals 


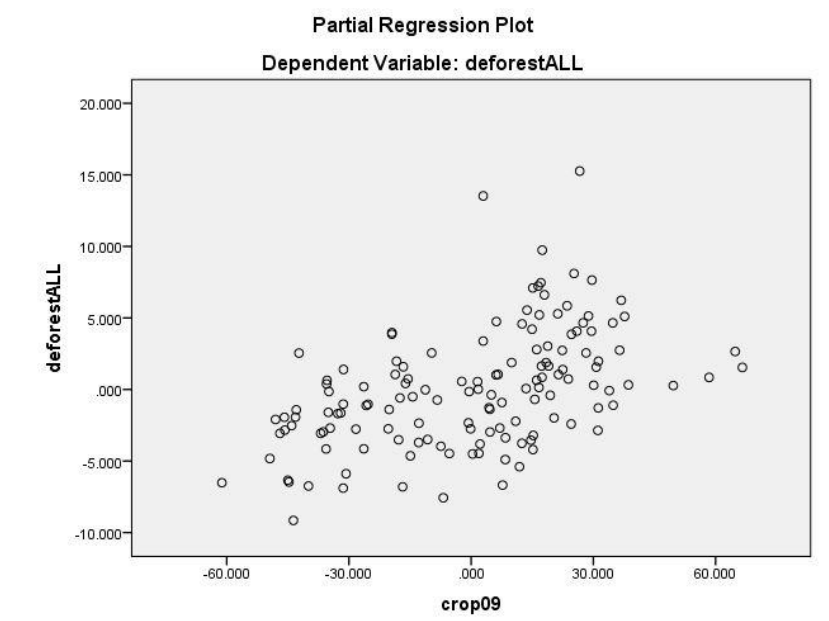

Plot 7: Cropland Residuals

Stepwise Method- can be used to assess the extent to which the most influential variables influence a dependent variables

\section{Regression Equation [model 1]: $Y_{p}=-0.009+0.097 C R O P$ \\ Regression Equation [model 2]: Yp $=-6.430+0.076$ CROP + 0.107 ELEC}

The positive correlation between cropland area and deforestation is to be expected (TABLE 7). The fact that cropland is more significantly influential than built-up areas however, is surprising. Regression model 2 has a higher $r$ squared than model 1, which means the two variables of cropland and energy access combined explain more variation in deforestation than cropland alone (TABLE 8). Stepwise method is useful in revealing which two indicators are most closely associated with deforestation, and especially in the case of this research because of the particular interest in energy access. Energy access emerged in this analysis as a factor which more strongly associated with deforestation than population density and built-up area.

\begin{tabular}{|c|c|c|c|c|c|c|c|c|c|c|c|}
\hline \multicolumn{12}{|c|}{ Coefficients $^{\mathrm{a}}$} \\
\hline \multirow[b]{2}{*}{ Model } & & \multicolumn{2}{|c|}{ Unstandardized Coefficients } & \multirow{2}{*}{$\begin{array}{c}\text { Standardized } \\
\text { Coefficients } \\
\text { Beta }\end{array}$} & \multirow[b]{2}{*}{$t$} & \multirow[b]{2}{*}{ Sig. } & \multicolumn{3}{|c|}{ Correlations } & \multicolumn{2}{|c|}{ Collinearity Statistics } \\
\hline & & B & Std. Error & & & & Zero-order & Partial & Part & Tolerance & VIF \\
\hline \multirow[t]{2}{*}{1} & (Constant) & -.009 & .624 & & -.015 & .988 & & & & & \\
\hline & crop09 & .097 & .010 & .649 & 9.973 & .000 & .649 & .649 & .649 & 1.000 & 1.000 \\
\hline \multirow[t]{3}{*}{2} & (Constant) & -6.430 & 1.384 & & -4.645 & .000 & & & & & \\
\hline & crop09 & .076 & .010 & .507 & 7.690 & .000 & .649 & .551 & .460 & .823 & 1.215 \\
\hline & ELECTRCHH14 & .107 & .021 & .336 & 5.097 & .000 & .550 & .400 & .305 & .823 & 1.215 \\
\hline
\end{tabular}




\begin{tabular}{|c|c|c|c|c|c|c|c|c|c|c|c|}
\hline \multirow[b]{4}{*}{ Model } & \multirow[b]{4}{*}{$\mathrm{R}$} & \multirow{2}{*}{\multicolumn{2}{|c|}{ Model Summary }} & \multirow{4}{*}{$\begin{array}{l}\text { Std. Error of } \\
\text { the Estimate }\end{array}$} & \multicolumn{6}{|c|}{ ANOVA $^{a}$} & \multirow{3}{*}{$\frac{\text { Sig. }}{.000}$} \\
\hline & & & & & \multicolumn{2}{|c|}{ Model } & $\begin{array}{l}\text { Sum of } \\
\text { Squares }\end{array}$ & \multirow{2}{*}{$\frac{d f}{1}$} & \multirow{2}{*}{$\begin{array}{r}\text { Mean Square } \\
1538.322\end{array}$} & \multirow{2}{*}{$\frac{F}{99.457}$} & \\
\hline & & & & & 1 & Regression & 1538.322 & & & & \\
\hline & & R Square & Square & & & Residual & 2119.015 & 137 & 15.467 & & \\
\hline 1 & $.649^{a}$ & .421 & .416 & 3.932844 & & Total & 3657.337 & 138 & & & \\
\hline 2 & $.717^{\mathrm{b}}$ & .514 & .506 & 3.616914 & 2 & Regression & 1878.176 & 2 & 939.088 & 71.784 & $.000^{\circ}$ \\
\hline a. $P$ & tors: (C & nstant) crop & & & & Residual & 1779.161 & 136 & 13.082 & & \\
\hline$P$ & tors. & nstant) cron & FI ECTRCHI & & & Total & 3657.337 & 138 & & & \\
\hline D. $\Gamma$ & (U) & - ilstamit, chop & פ, ELECIRU & & & ependent Vari & deforestALL & & & & \\
\hline C. & inemil va & rave. delore & ALL & & & edictors: (Con & t), crop09 & & & & \\
\hline & & & & & & edictors: (Con & t), crop09, EL & $\mathrm{RCHH} 1$ & & & \\
\hline & Table & : Stepwis & Model Sum & ary & & & Table & tepwi & ANOVA & & \\
\hline
\end{tabular}

\section{Cluster Analysis}

The cluster analysis reveals that there are apparent district characteristics (TABLE 10). These distinctions are distinguishable through non-spatial statistical means of cluster analysis. The results show that there are two clusters with relatively high rates of deforestation. One of these clusters, cluster \#3, is also characterized by high built-up area and population density. This leads to the assumption that cluster \#3 is urban districts. Urban districts apparently are characterized by high rates of wood use as cooking fuel and expected high rates of energy access and education.

Cluster \#1 districts are characterized by high cropland area and high deforestation with average values of other variables. Cluster \#4 appears to be rural, sparsely populated areas. These districts are low in population density, low in deforestation, low in cropland, low in education, low in energy access and unexpectedly low in use of wood as cooking fuel. This is an important finding, as it contradicts our assumption that rural areas with low energy access depend on wood as a source of fuel for cooking. 


\begin{tabular}{|c|c|c|c|c|c|c|c|c|c|c|}
\hline \multicolumn{11}{|c|}{ Report } \\
\hline \multicolumn{2}{|c|}{ Ward Method } & $\begin{array}{c}\text { COOKFUEL1 } \\
4\end{array}$ & $\begin{array}{c}\text { ELECTRCHH } \\
14\end{array}$ & EDUCLVL14 & \multicolumn{2}{|c|}{ Pop15 } & \multirow{2}{*}{$\begin{array}{l}\text { Built14 } \\
.279317\end{array}$} & \multicolumn{2}{|c|}{ deforestALL } & crop09 \\
\hline \multirow[t]{3}{*}{1} & Mean & 33.27 & 80.15 & 86.35 & \multicolumn{2}{|c|}{1676.89737} & & \multicolumn{2}{|c|}{9.89390} & 84.74098 \\
\hline & $\mathrm{N}$ & 52 & 52 & 52 & & 52 & 52 & \multicolumn{2}{|r|}{52} & 52 \\
\hline & Std. Deviation & 7.171 & 7.547 & 3.080 & \multicolumn{2}{|c|}{653.118252} & .0813191 & 3.98 & 2548 & 11.189447 \\
\hline \multirow[t]{3}{*}{2} & Mean & 35.93 & 75.28 & 84.07 & \multicolumn{2}{|c|}{1421.47321} & .209724 & \multicolumn{2}{|c|}{1.98641} & 41.21990 \\
\hline & N & 29 & 29 & 29 & & 29 & 2 & & 29 & 29 \\
\hline & Std. Deviation & 6.307 & 8.044 & 7.483 & \multicolumn{2}{|c|}{642.738452} & .0871568 & 1.76 & 8436 & 22.021094 \\
\hline 3 & Mean & 44.00 & 89.91 & 91.36 & 6162.7 & 4255 & .64747 & & 3764 & 66.28200 \\
\hline & N & 11 & 11 & 11 & & 11 & 11 & & 11 & 11 \\
\hline & Std. Deviation & 4.123 & 3.859 & 1.748 & 2512.59 & 5146 & $.171153 c$ & 6.57 & 2153 & 35.597929 \\
\hline 4 & Mean & 22.19 & 53.06 & 60.09 & 923.0 & 4268 & .10348 & & 2166 & 24.83932 \\
\hline & N & 47 & 47 & 47 & & 47 & 47 & & 47 & 47 \\
\hline & Std. Deviation & 5.182 & 12.602 & 12.279 & 281.05 & 1619 & .045704 & 1.55 & 7692 & 27.115301 \\
\hline Total & Mean & 30.93 & 70.75 & 77.39 & 1723.7 & 0187 & .23447 & & 4835 & 53.94574 \\
\hline & N & 139 & 139 & 139 & & 139 & 13 & & 139 & 139 \\
\hline & Std. Deviation & 9.176 & 16.174 & 14.916 & 1591.95 & 2380 & $.164713 s$ & 5.14 & 8052 & 34.258046 \\
\hline & & & & Table 10: Clus & ter Rep & & & & & \\
\hline & & & & ANOV & & & & & & \\
\hline & & & & $\begin{array}{l}\text { Sum of } \\
\text { Squares }\end{array}$ & df & Mean & n Square & $\mathrm{F}$ & Sig. & \\
\hline & & COOKFUEL14 & Between Groups & 6477.911 & 3 & & 2159.304 & 56.698 & & 00 \\
\hline & & & Within Groups & 5141.369 & 135 & & 38.084 & & & \\
\hline & & & Total & 11619.281 & 138 & & & & & \\
\hline & & ELECTRCHH14 & Between Groups & 23931.907 & 3 & & 7977.302 & 88.489 & & 00 \\
\hline & & & Within Groups & 12170.280 & 135 & & 90.150 & & & \\
\hline & & & Total & 36102.187 & 138 & & & & & \\
\hline & & EDUCLVL14 & Between Groups & 21687.185 & 3 & & 7229.062 & 108.221 & & 00 \\
\hline & & & Within Groups & 9017.836 & 135 & & 66.799 & & & \\
\hline & & & Total & 30705.022 & 138 & & & & & \\
\hline & & Pop15 & Between Groups & 249648331.9 & 3 & 8321 & 16110.64 & 112.244 & & 00 \\
\hline & & & Within Groups & 100086776.4 & 135 & & 1383.529 & & & \\
\hline & & & Total & 349735108.3 & 138 & & & & & \\
\hline & & Built1 4 & Between Groups & 2.805 & 3 & & .935 & 134.432 & & 00 \\
\hline & & & Within Groups & .939 & 135 & & .007 & & & \\
\hline & & & Total & 3.744 & 138 & & & & & \\
\hline & & deforestALL & Between Groups & 2217.329 & 3 & & 739.110 & 69.291 & & 00 \\
\hline & & & Within Groups & 1440.008 & 135 & & 10.667 & & & \\
\hline & & & Total & 3657.337 & 138 & & & & & \\
\hline & & cropog & Between Groups & 95502.154 & 3 & & 1834.051 & 64.668 & & 00 \\
\hline & & & Within Groups & 66456.535 & 135 & & 492.271 & & & \\
\hline & & & Total & 161958.689 & 138 & & & & & \\
\hline
\end{tabular}

\section{Bivariate LISA}

The highest Moran's I scores were above 0.5 for Electricity Access, Education and Cropland Area which means these have strong spatial autocorrelation with deforestation. The 
resulting cluster maps reveal that the northern districts have a trend of low deforestation with low rates of all variables while districts closer to the coastline in the south have higher rates of deforestation with high rates of many of the independent variables. The built-up and population density maps indicate that urbanization and population growth demands only drive deforestation in the few red districts corresponding to the urban areas shown in FIGURE 1, FIGURE 6 and FIGURE 7.

The spatial autocorrelation between energy access and deforestation is of interest in this study. The Bivariate LISA output shows a strong spatial relationship that is majority positive but negative for a few districts in the south. This suggests that high rates of deforestation occur in proximity to districts with high rates of energy access while low rates of deforestation occur in proximity to districts with low rates of energy access. This opposes the findings of the Tanner research.

The relationship between deforestation and wood use as cooking fuel is also interesting (FIGURE 4). There are only a few districts, which show the relationship as expected, high deforestation occurring where there is high use of wood as cooking fuel. The general trend is that of low use of wood as cooking fuel and low deforestation, which is also to be expected.

The resulting cluster maps for population and built-up area were not surprising. It was expected that deforestation would be associated with districts with high populations and high infrastructure. Cropland BiLISA output has the most red districts (FIGURE 8). This aligns with the findings of the stepwise regression, which suggest cropland area is most highly correlated with deforestation. The cluster of red districts represent a large patch of districts with high percentages of cropland area which also have high forest rates of forest loss (FIGURE 2). 


\section{Population Density in Ghana 2015}

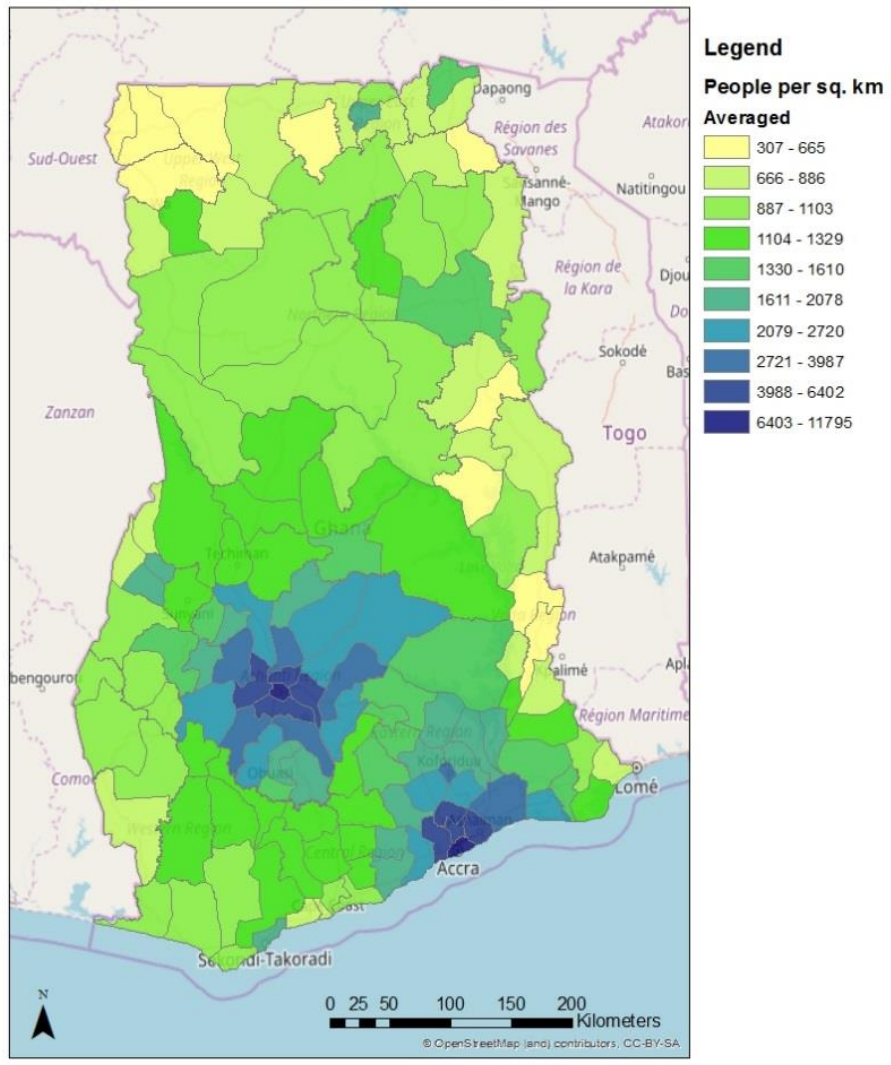

Figure 1: Population Density

\section{Cropland Area: Ghana 2009}

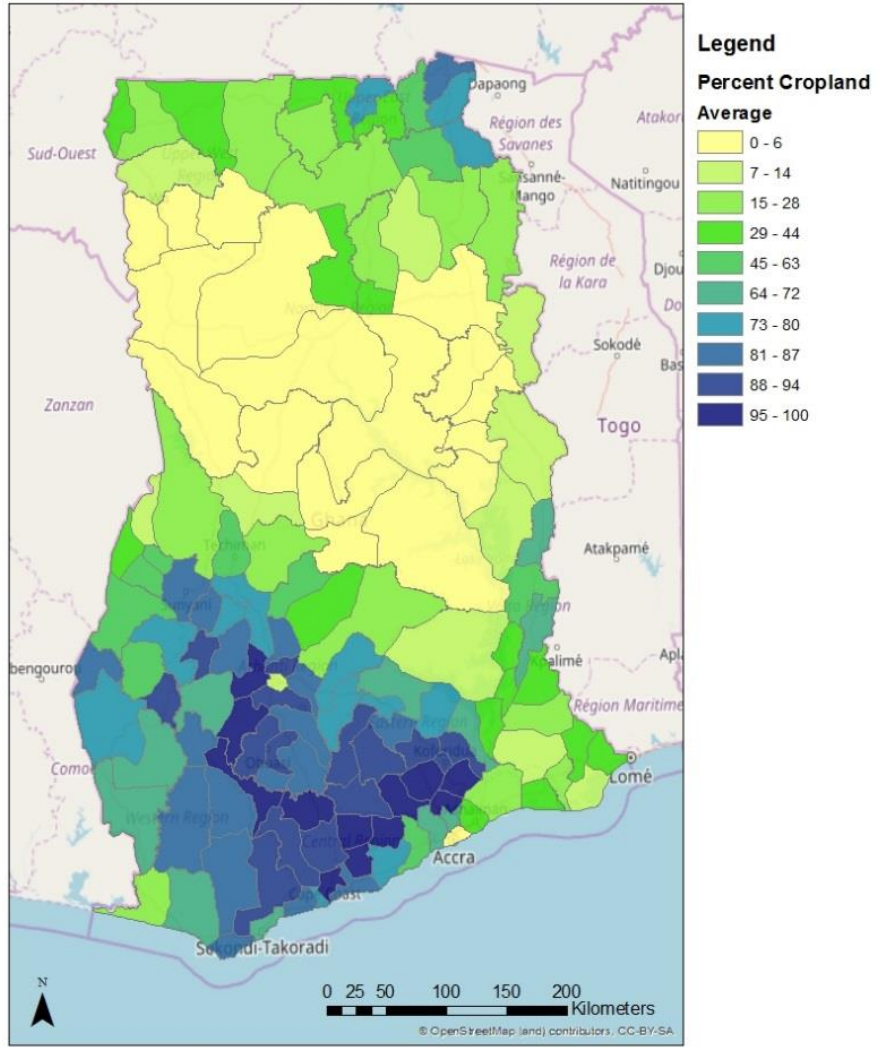

Figure 2: Cropland

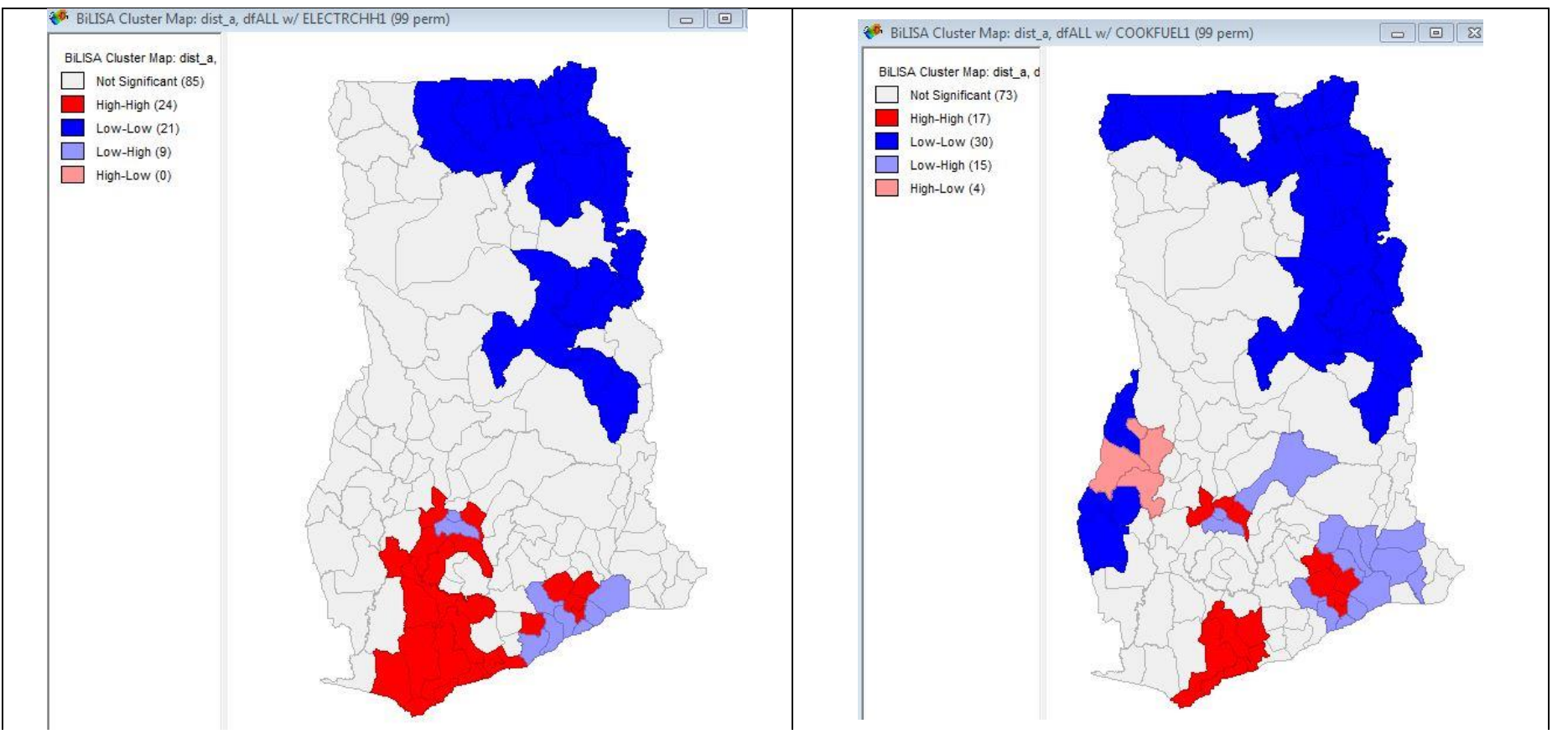


Moran's I: $\mathbf{0 . 5 2 6 6 8 7}$ [Electricity] Figure 3: Electricity BiLISA

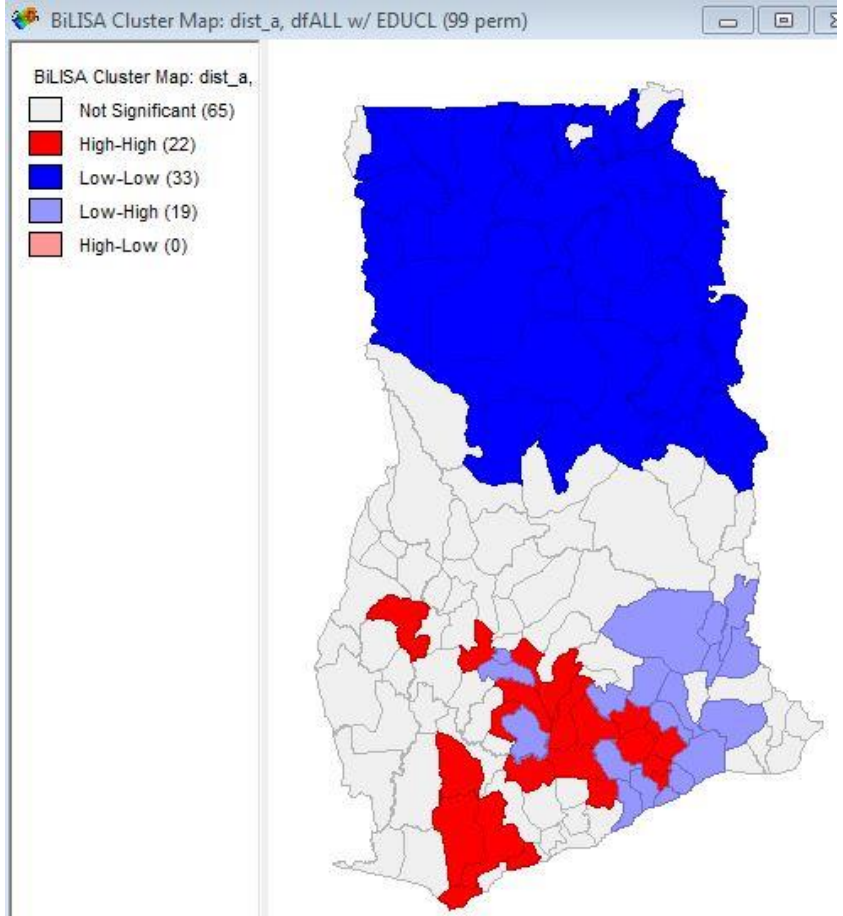

Moran's I: 0.512898 [Education] Figure 5: Education BiLISA

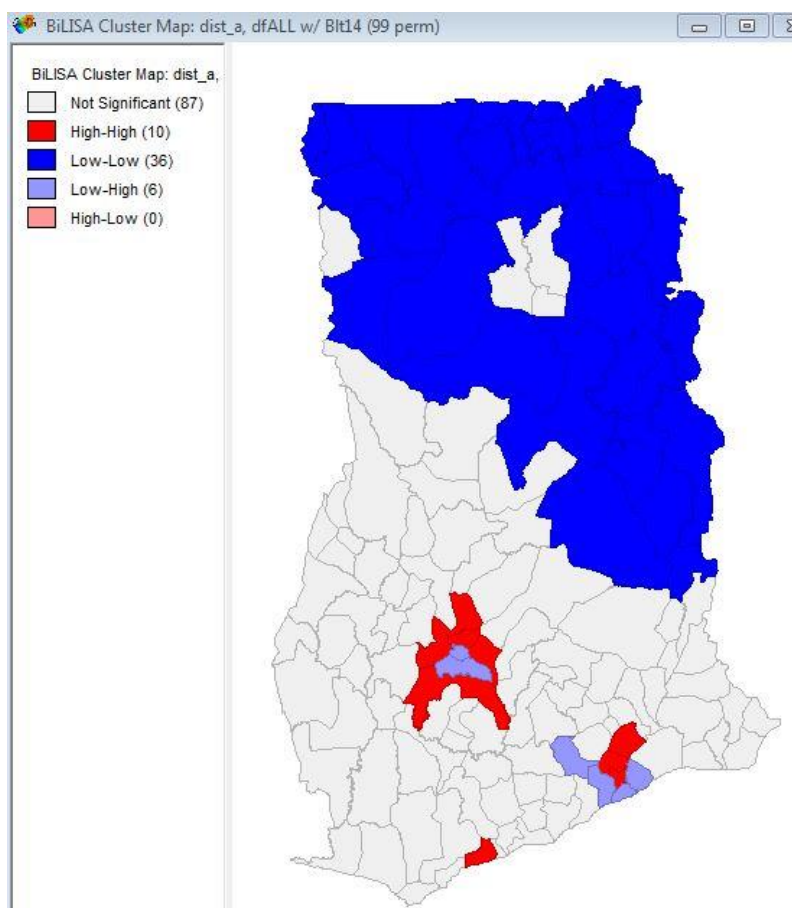

Moran's I: 0.373956 [Built-Up Area]

Figure 7: Built-Up Area BiLISA
Moran's I: 0.354059 [Cook Fuel] Figure 4: Wood use BiLISA

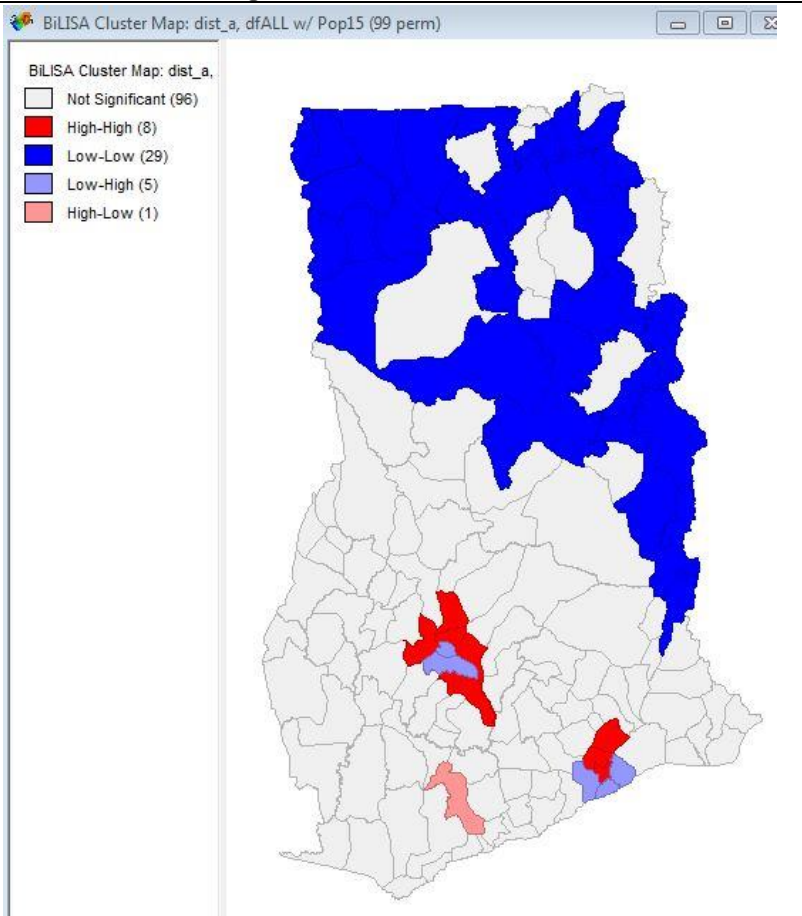

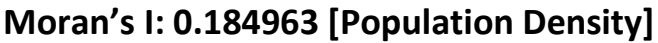
Figure 6: Population Density BiLISA

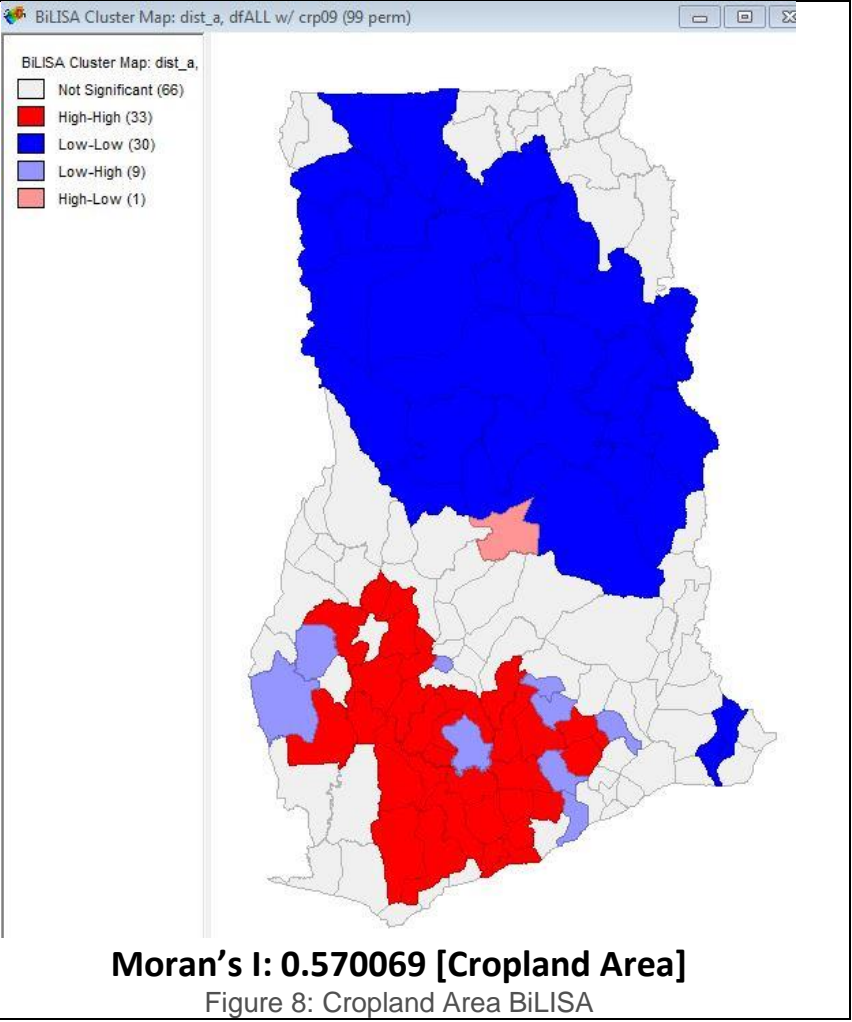




\section{Summary and Conclusions}

The cluster analysis revealed that the initial research assumption was in fact incorrect. The cluster characteristics contradict our assumption that rural areas with low energy access depend on wood as a source of fuel for cooking. The cluster representing urban areas have the highest rate of wood use as a cooking fuel while the rural districts cluster has the lowest rate of wood use as cooking fuel. This may be because Ghanaian rural communities lack the resources to access forests for wood fuel sources, wood as cooking fuel sources are too expensive for rural communities to utilize, or that use of more prevalent resources like animal dung or crop residues are the norm. This exemplifies the importance of background research and local knowledge in conducting analysis of unfamiliar developing countries.

The positive correlation between cropland area and deforestation revealed by the stepwise multivariate regression is to be expected. The fact that cropland is more significantly influential than built-up areas implies that urban expansion is not effecting deforestation rates as much as more traditional economic drivers such as agriculture. The prevalence of agriculture in Ghana is the culprit for energy access showing a positive relationship with deforestation. Energy access is theorized to reduce dependence on wood as a fuel source therefore decreasing deforestation rates, but what has been found through the cluster analysis is that wood use as a fuel is low in rural areas with low energy access. Energy access also enables expansion of economies and agricultural sectors; this second scenario is what appears to be happening as the result of energy access in Ghana.

The last method of analysis, BiLISA, further proved that high deforestation is mostly associated with agricultural production as seen by the prevalence of red districts in FIGURE. Rather than reducing deforestation, energy access enables improvement of economic activities, which in this case is agriculture. Agriculture emerged as a driving force of deforestation in the stepwise multivariate regression and can be identified as the biggest threat to forests in Ghana. 


\section{Sources}

ESA. 2009. ESA GlobCover: Global Land Cover Map. Google Earth Engine [online]. Accessed: November 2017. Available from:

https://explorer.earthengine.google.com/\#detail/ESA\%2FGLOBCOVER L4 200901200912 V2 3

Demographic and Health Survey (DHS). 2016. DHS Survey Program Data [online]. Accessed: November 2017. Available from: https://dhsprogram.com/data/available-datasets.cfm

Demographic and Health Survey (DHS). 2017. IPUMS Database [online]. Accessed: November 2017. Available from: https://www.idhsdata.org/idhs/

Humanitarian Data Exchange (HDX). April 2005. Ghana-Administrative Boundaries. OCHA [online]. Accessed: November 2017. Available from: https://data.humdata.org/dataset/ghana-administrativeboundaries

NASA/USGS. 2013. Hansen Global Forest Change v1.3 (200-2015). Google Earth Engine [online]. Accessed: November 2017. Available from: https://explorer.earthengine.google.com/\#detail/UMD\%2Fhansen\%2Fglobal forest change 2015 v1 3

Tanner, Andrew M., Johnston, Alison L. June 2017. The Impact of Rural Electric Access on Deforestation Rates [online]. World Development Journal. Accessed: November 2017. Available From: http://www.sciencedirect.com/science/article/pii/S0305750X17300025 